\title{
PROBLEMATIKA EKSEKUSI HARTA PAILIT DALAM CROSS BORDER INSOLVENCY
}

\author{
Lia Nopiharni Puspitasari S, Dian Septiandani, Diah Sulistyani RS, Kadi Sukarna \\ Magister Hukum Universitas Semarang, Semarang \\ lianopiharni94@gmail.com
}

\begin{abstract}
Abstrak
Penelitian ini bertujuan untuk mengetahui praktek eksekusi harta pailit yang di dalam pelaksanaannya terdapat problematika dan juga mekanisme pemberesan harta pailit dalam cross border insolvency. Terkait dengan adanya kepailitan lintas batas negara, Indonesia belum mengatur mengenai peraturan yang mengatur mengenai hal tersebut sehingga muncul sebuah problematika dalam eksekusi kepailitan lintas batas negara. Metode penelitian yang digunakan yaitu metode pendekatan yuridis normatif. Cross border insolvency dapat terjadi apabila aset atau utang seorang debitur terletak di lebih dari satu negara atau apabila debitur termasuk ke dalam yurisdiksi pengadilan pada dua atau lebih negara. Dalam kaitannya dengan kasus kepailitan yang bersifat lintas batas, sering terjadi suatu keadaan dimana terdapat debitor yang akan digugat pailit berkedudukan di suatu negara, tetapi ia juga melakukan kegiatan usaha dan memiliki aset di luar negeri. Begitupun sebaliknya, debitor asing yang akan digugat pailit, tetapi ia memiliki kegiatan usaha ataupun aset di Indonesia. Hal tersebut mengakibatkan keadaan harta debitur yang melintasi batas negara sering menimbulkan permasalahan mengenai batasan harta debitur yang termasuk ke dalam boedel pailit.

Kata kunci : Cross Border Insolvency; Pailit; Problematika
\end{abstract}

\section{EXECUTION PROBLEMS IN BANKRUPT ASSETS CROSS BORDER INSOLVENCY}

\begin{abstract}
This study aims to determine the practice of executing bankrupt assets in which there are problems and also the mechanism for the settlement of bankrupt assets in cross-border insolvency. Regarding the existence of cross-border insolvency, Indonesia has not yet regulated the regulations governing this matter so that a problem arises in the execution of cross-border insolvency. The research method used is normative juridical. Cross-border insolvency can occur if the assets or debts of the debtor are located in more than one country or if the debtor falls under the jurisdiction of courts in two or more countries. In relation to crossborder insolvency cases, there is often a situation where there is a debtor who will be sued for bankruptcy based in a country, but he also conducts business activities and owns assets abroad. Vice versa, the foreign debtor will be sued for bankruptcy, but he has business activities or assets in Indonesia. This has resulted in the condition of the debtor's assets crossing national borders, often causing problems regarding the limits of debtor assets which are included in the bankrupt account.
\end{abstract}

Keyword: Cross Border Insolvency; Bankruptcy; Problem 


\section{A. PENDAHULUAN}

Pertumbuhan ekonomi dunia sedang mengalami disrupsi akibat adanya perang dagang antara Amerika Serikat (AS) dan China. Perang dagang yang belum kunjung usai memberikan efek domino ke berbagai negara. Bagi wilayah ASEAN, perang dagang memberikan tantangan dan peluang. Tantangan muncul karena ekonomi dunia yang melambat, sementara peluang hadir untuk meningkatkan sektor manufaktur karena ASEAN dinilai sebagai alternatif bisnis selain China. Indonesia sendiri merupakan negara dengan penduduk yang besar banyak. Dari banyak nya pertumbuhan penduduk tersebut, secara tidak langsung mempengaruhi pertumbuhan ekonomi. Menurut laporan The Economist, pertumbuhan ekonomi di ASEAN melambat tetapi masih dalam taraf baik. Pertumbuhan Indonesia pun diprediksi tetap berada pada kisaran 5,2 persen tahun ini. ${ }^{1}$ Kemajuan dalam teknologi informasi dan komunikasi telah mendorong masyarakat untuk memasuki fase perkembangan globalisasi. Globalisasi mengarah pada kondisi suatu proses yang menempatkan masyarakat dunia dapat menjangkau satu dengan yang lain atau saling terhubungkan dalam aspek kehidupan mereka, baik dalam budaya, ekonomi, politik, teknologi maupun lingkungan. ${ }^{2}$

Perkembangan yang terjadi di dalam masyarakat akibat globalisasi telah mempengaruhi perkembangan dalam tatanan hukum nasional bangsa-bangsa. Pada akhirnya, norma-norma hukum yang ada harus menyesuaikan diri dengan perubahanperubahan akibat globalisasi tersebut. Hal tersebut bukan berarti harus melepaskan diri dari nilai-nilai keberlakuan yang terdapat dalam nilai-nilai pandangan hidup, ideologi dan dasar negara Pancasila yang telah menjadi sumber dari segala sumber hukum yang ada. Untuk itu hukum harus mampu memadukan implikasi yang timbul akibat arus globalisasi dan nilai-nilai dasar yang dikandung dalam Pancasila sebab manakala hukumnya berhenti tidak mampu mengikuti akselerasi perkembangan maka hukum akan kehilangan fungsinya di masyarakat, hukum menjadi tidak memiliki jati diri, hakikat dari sebuah tatanan hukum yang sudah sepatutnya mengatur kehidupan masyarakat menuju tujuan mulia yaitu ketertiban dan keadilan yang tidak ada.

Hukum harus mampu memberikan pengaturan pada seluruh aspek manusia, apalagi di era globalisasi seperti sekarang. Hukum sangat penting dalam menjalankan dunia bisnis, apalagi ketika bisnis tersebut dikelola di luar negeri atau di luar teritorial Indonesia dan negara-negara lain. Mengingat di era globalisasi, tiap negara harus memiliki sikap keterbuakaan akibat posisi yang bordeless kedaulatan teritorial negara menjadi tipis batasnya sehingga perkembangan dunia akan berimbas pada bagian wilayah negara lain. Isu-isu transparansi global, demokaratisasi, civil society, hak asasi manusia, akuntabilitas public, non diskriminasi telah dengan cepat mempengaruhi keberlakuan norma hukum. ${ }^{3}$

\footnotetext{
${ }^{1}$ https://www.liputan6.com/bisnis/read/4020268/melihat-pertumbuhan-ekonomi-di-asean-indonesiaperingkat-berapa, diakses pada tanggal 17 Januari 2021 pukul 15.30 WIB.

${ }^{2}$ Budi Winarno, Globalisasi Wujud Imperlism Baru Peran Negara Dalam Perkembangan, (Yogyakarta: Tajidu Press, 2004): 39.

${ }^{3}$ Endang Sutrisno, Bunga Rampai Hukum dan Globalisasi,(Jakarta: In Media, 2013): 83.
} 
Dunia bisnis pun dilakukan bukan hanya di dalam negaranya sendiri, tetapi dunia bisnis sekarang sudah berkembang menjalin hubungan bisnis dengan negara lain di dunia (transnasional). Dengan begitu aset yang dimiliki debitur ataupun kreditur tidak berada didalam negaranya sendiri namun ada beberapa di negara lain. Hubungan bisnis yang dijalankan antar debitur dan kreditur tidak selamanya berjalan lancar, dalam hubungan bisnis tersebut mengalami kegagalan maka akan terjadi baik aset debitur maupun para kreditur berada di beberapa negara dan hal inipun menjadikan terjadinya multipe jurisdiction. Selayaknya dalam kegiatan bisnis, perkembangan investasi asing di ASEAN juga menimbulkan resiko yang tidak dapat dihindari. Sebenarnya, dibalik keuntungan yang menjanjikan dengan melakukan investasi asing, perusahaan multinasional yang notabene sebagai pelaku dalam berinvestasi asing memiliki resiko bangkrut atau pailit yang cukup besar. ${ }^{4}$

Hukum kepailitan merupakan hukum nasional yang hanya berlaku di wilayah dari negara hukum yang bersangkutan, sehingga hukum kepailitan suatu negara tidak bisa menjangkau kepailitan yang terjadi di negara lain. Sedangkan, kepailitan itu sendiri merupakan putusan pengadilan yang mengakibatkan sita umum atas seluruh kekayaan debitur pailit, baik yang telah ada maupun yang akan ada di kemudian hari. ${ }^{5}$ Kepailitan adalah merupakan pelaksanaan lebih lanjut dari prinsip paritas creditorium dan prinsip pari passu prorate parte dalam rezim hukum harta kekayaan (vermogensrechts). Prinsip paritas creditorium berarti semua kekayaan debitur baik yang berupa barang bergerak ataupun barang tidak bergerak maupun harta yang sekarang telah dipunyai debitur dan barang-barang kemudian hari akan dimiliki debitur terikat kepada penyelesaian kewajiban debitur. ${ }^{6}$ Sedangkan, prinsip pari passu prorate parte artinya bahwa harta kekayaan tersebut merupakan jaminan bersama untuk para kreditur dan hasilnya harus dibagikan secara rata antara mereka, kecuali jika antara para kreditur tersebut ada yang menurut undang-undang harus didahulukan dalam menerima pembayaran tagihan.

Di Indonesia kepailitan telah diatur dalam Undang-Undang Nomor 37 Tahun 2004 tentang Kepailitan dan Penundaan Kewajiban Pembayaran Utang, namun dalam kaitannya dengan cross border insolvency dalam undang-undang tersebut tidak mengatur secara jelas mengenai kepailitan lintas batas negara. Oleh karena itu, sampai saat ini sering terjadi problematika dalam pelaksanaan mekanisme pemberesan harta pailit dalam cross border insolvency. Meskipun ada UNCITRAL Model Law on Cross-Border Insolvency With Guide to Enactment yang telah diadopsi oleh beberapa negara sejak tahun 1997, namun hingga saat ini belum ada aturan hukum di Indonesia yang secara tegas dapat diterapkan dalam perkara kepailitan lintas batas negara. Undang-Undang Kepailitan sendiri belum memiliki aturan hukum yang jelas untuk menangani kasus kepailitan lintas negara. Tidak adanya ketentuan khusus mengenai cara menyelesaikan

\footnotetext{
${ }^{4}$ Pramesthi Dinar Kirana Ratri dan Emmy Latifah, "Urgensi Penerapan Aturan Kepailitan Lintas Batas Negara Berdasarkan UNCITRAL Model Law On Cross-Border Insolvency di ASEAN, Belli ac Pacis 2, no. 2 (2016): 7 , https://jurnal.uns.ac.id/belli/article/view/27448/18982

${ }^{5}$ Susanti Adi Nugroho, Hukum Kepailitan di Indonesia, (Jakarta: Prenadamedia Group, 2018): 1.

${ }^{6}$ Hadi Shubhan, Hukum Kepailitan: Prinsip, Norma, dan Praktik di Peradilan,cetakan ke-6, (Jakarta: Prenadamedia Group, 2019): 3.
} 
putusan pailit lintas negara di Pengadilan Niaga Indonesia terhadap aset debitur yang berada di luar negeri menimbulkan suatu permasalahan dalam hal eksekusinya.

Penelitian terdahulu yang relevan dengan penelitian ini dikaji oleh Amalia (2015) yang berjudul "Urgensi Implementasi UNCITRAL Model Law On Cross-Border Insolvency di Indonesia : Studi Komparasi Hukum Kepailitan Lintas Batas Indonesia dan Singapura". Penelitian tersebut bertujuan untuk mengetahui penerapan UNCITRAL Model Law dalam hukum kepailitan Indonesia. Permasalahan yang dibahas pada penelitian tersebut yaitu bagaimana UNCITRAL Model Law memberi pedoman terkait hukum kepailitan lintas batas dan bagaimana urgensi implementasi dalam hukum kepailitan lintas batas di Indonesia dan Singapura. ${ }^{7}$ Metode penelitian yang digunakan yaitu yuridis normatif. Perbedaan terletak pada permasalahan dimana dalam penelitian ini membahas mengenai mekanisme yang diterapkan di Indonesia apabila terdapat kasus kepailitan lintas batas negara, dimana pada dasarnya Indonesia belum mempunyai kekuatan hukum yang tetap apabila menangani kasus cross border insolvency, sehingga dalam penerapannya sering menimbulkan problematika karena tidak adanya aturan khusus yang mengatur mengenai hal tersebut.

Sedangkan penelitian oleh Ganindha (2020) yang berjudul "Kewenangan Kurator Dalam Eksekusi Aset Debitur Pada Kepailitan Lintas Batas Negara." Penelitian tersebut bertujuan untuk mengetahui dan menganalisa kewenangan kurator dalam mengeksekusi boedel pailit yang berada diluar batas yurisdiksi Indonesia. Permasalahan dalam penelitian tersebut yaitu bagaimanakah kewenangan kurator dalam mengeksekusi boedel pailit yang berada diluar batas yurisdiksi Indonesia. Perbedaan antara penelitian terdahulu dengan penelitian saat ini ialah pada penelitian ini tidak secara spesifik menjelaskan mengenai kewenangan kurator dalam mengeksekusi boedel pailit di luar batas yurisdiksi Indonesia, melainkan hanya membahas secara singkat dan termasuk dalam mekanisme pemberesan harta pailit cross border insolvency. Kurator sebagai pihak yang berwenang untuk mengeksekusi boedel pailit dapat melakukan eksekusi terhadap seluruh harta debitur yang berada di luar batas yurisdiksi Indonesia. Namun, dalam prinsip universalitas dalam undang-undang tersebut berbenturan dengan prinsip teritorialitas yang dianut Indonesia terhadap putusan pailit pengadilan asing mengenai boedel pailit yang berada di Indonesia. Sehingga, jika terdapat debitur asing yang memiliki aset di Indonesia maka aset tersebut tidak dapat di eksekusi karena tidak adanya pengaturan dalam perundang-undangan di Indonesia yang menyatakan bahwa putusan pailit pengadilan asing dapat diakui serta dilaksanakan di Indonesia. ${ }^{8}$

Sedangkan penelitian oleh Satrio (2020) yang berjudul "Eksekusi Harta Debitur Pailit yang Terdapat di luar Indonesia Dihubungkan dengan Pemenuhan Hak-Hak Kreditur." Penelitian tersebut bertujuan untuk menganalisa kekuatan eksekutorial putusan

${ }^{7}$ Jihan Amalia, "Urgensi Implementasi UNCITRAL Model Law On Cross-Border Insolvency di Indonesia : Studi Komparasi Hukum Kepailitan Lintas Batas Indonesia dan Singapura", Jurnal Hukum Bisnis Bonum Commune 2, no. 2 (2019): 164, https://core.ac.uk/download/pdf/229337923.pdf

${ }^{8}$ Ranitya Ganindha dan Nadhira Putri Indira, "Kewenangan Kurator Dalam Eksekusi Aset Debitor Pada Kepailitan Lintas Batas Negara”, Arena Hukum 13, no. 2 (2020): 337, https://doi.org/10.21776/ub.arenahukum.2020.01302.8 
kepailitan pengadilan niaga di Indonesia terhadap harta debitur pailit yang terdapat di luar Indonesia dan tindakan hukum kurator untuk melakukan eksekusi terhadap harta debitur pailit yang terdapat di luar Indonesia. Perbedaan yang terjadi antara kedua penelitian tersebut ialah tidak membahas mengenai problematika dalam penerapan cross border insolvency, melainkan terhadap harta debitur pailit yang terdapat di luar Indonesia tidak dapat dilakukan, karena putusan kepailitan yang telah dijatuhkan oleh Pengadilan Niaga Indonesia tidak memiliki kekuatan eksekutorial atas harta debitur pailit yang terdapat diluar Indonesia, maka segala akibat dari adanya putusan pernyataan pailit tidak mengikat terhadap harta debitur pailit yang berada di luar Indonesia. ${ }^{9}$

Kelebihan penelitian ini dengan penelitian terdahulu yaitu apabila pada penelitian ini membahas lebih lanjut dan spesifik mengenai problematika yang terjadi dalam kaitannya dengan eksekusi harta pailit dalam kasus cross border insolvency. Perbedaan dengan penelitian sebelumnya belum membahas secara detail bagaimana mekanisme yang seharusnya dilakukan dalam mengeksekusi kasus cross border insolvency, karena memang dari segi peraturan hukum Indonesia belum mengatur secara khusus mengenai hal tersebut.Tujuan dari penelitian ini yakni untuk mengetahui praktek eksekusi harta pailit dalam cross border insolvency serta mekanisme pemberesan harta pailit yang dilakukan dan juga problematika selama melaksanakan eksekusi.

\section{B. PERMASALAHAN}

Penelitian ini merumuskan permasalahan tentang bagaimana praktek eksekusi harta pailit dalam cross border insolvency serta problematika eksekusi harta pailit dalam cross border insolvency dan juga mekanisme pemberesan harta pailit dalam cross border insolvency?

\section{METODE PENELITIAN}

Metode penelitian yang digunakan dalam penelitian ini yaitu metode pendekatan yuridis-normatif. Pendekatan yuridis normatif meneliti bahan-bahan kepustakaan (data sekunder) yang mencakup mengenai asas-asas hukum, sistematika hukum, sinkronisaisi vertikal dan horizontal, perbandingan hukum, dan sejarah hukum. Pendekatan yuridis normatif menitik beratkan pada penelitian menggunakan bahan-bahan hukum.

Penggunaan teori penelitian ini menggunakan teori keadilan hukum, kepastian hukum, dan perlindungan hukum sejauh mana ketiga teori tersebut diterapkan dalam praktek pemberesan harta pailit dalam cross border insolvency.

Analis data yang digunakan dilakukan secara kualitatif yang dipadukan dengan metode kuantitaif. Data penelitian diperoleh dengan melakukan pengukuran atas variabel yang sedang diteliti. Membuat instrument atau skala penelitian. ${ }^{\mathbf{1 0}}$

\footnotetext{
${ }^{9}$ Adi Satrio., et. al, "Eksekusi Harta Debitor Pailit Yang Terdapat Di Luar Indonesia Dihubungkan Dengan Pemenuhan Hak-Hak Kreditur", Ganesha Law Review 2, no. 1 (2020): 101-106, https://ejournal2.undiksha.ac.id/index.php/GLR/article/download/126/89

${ }^{10}$ H.B. Sutopo, Metodologi Penelitian Hukum Kualitatif Bagian II, (Surakarta: UNS Press, 1998): 37.
} 


\section{HASIL DAN PEMBAHASAN}

\section{Praktek Eksekusi Harta Pailit Dalam Cross Border Insolvency}

Pada umumnya, hukum kepailitan diperuntukkan bagi debitur yang tidak mampu membayar atau dengan kata lain berada dalam kondisi keuangan yang tidak sehat (insolvent). Oleh karena itu, dengan adanya peraturan kepailitan ini maka secara das sollen negara mencoba memberikan jalan keluar bagi debitur yang sedang mengalami kesulitan secara keuangan (financial disctress) supaya dapat melakukan pelunasan utang meskipun tidak secara penuh. Sebagaimana telah diketahui bahwasannya setiap transaksi bisnis yang dilakukan oleh pelaku usaha dengan pelaku usaha lain yang berbeda kewarganegaraan tidak terlepas dari pengaturan oleh negara. Maka dari itu, segala ketentuan yang mengatur mengenai transaksi bisnis yang dilakukan oleh pelaku usaha harus berpedoman pada ketentuan hukum yang berada dalam negara yang bersangkutan. ${ }^{11}$

Politik hukum selalu terjalin dan menjadi wilayah negara, baik di pusat maupun di wilayah terkecil negara tersebut. Ekspresi kemauan politik tidak diukur dari "berapa banyak undang-undang yang telah diundangkan", tetapi apakah sebagian besar masyarakat Indonesia. ${ }^{12}$ Tujuan dari pembangunan hukum nasional adalah dalam rangka mewujudkan masyarakat adil dan makmur, sehingga untuk mewujudkan sistem hukum nasional harus melalui pembentukan undang-undang baru, khususnya hukum. Produk hukum tersebut diperlukan untuk mendukung pembangunan ekonomi masyarakat. ${ }^{13}$ Undang-undang kepailitan merupakan salah satu solusi untuk pembangunan ekonomi skala besar masalah hutang perusahaan sangat berguna untuk memenuhi kebutuhan hukum para pelaku usaha untuk mengatasi masalah hutang dan perkreditan. ${ }^{14}$ Kebangkrutan memang tidak menjadi perhatian publik, juga tidak menarik, tetapi tibatiba menjadi proses likuidasi pinjaman yang bermasalah, dan pelaku usaha sangat membutuhkannya. Hal ini dibuktikan dengan meningkatnya jumlah permohonan pailit yang diajukan kepada Pengadilan Niaga Pusat Jakarta menjadi 100 perkara pailit yang diajukan pada tahun 1999. ${ }^{15}$

Kepailitan lintas batas negara (cross border insolvency) dapat terjadi jika permasalahan kepaitian mengandung unsur-unsur asing di dalamnya. Pada umumnya, cross border insolvency dapat terjadi bila aset atau utang seorang debitur terletak di lebih dari satu negara atau apabila debitur termasuk ke dalam yurisdiksi pengadilan pada dua atau lebih negara. Pengaturan mengenai cross border insolvency terdapat pada beberapa regulasi regional dan internasional yaitu the Europian Community Regulation Insolvency

${ }^{11}$ Dicky Moallavi, Asnil, "UNCITRAL Model Law on Cross Border Insolvency Sebagai Model Pengaturan Kepailitan Lintas Batas Indonesia dalam Integrasi Ekonomi ASEAN", Undang: Jurnal Hukum 1, no. 2 (2018): 328, https://ujh.unja.ac.id/index.php/home/article/view/22/15

12 Arif Hidayat, Zaenal Arifin, "Politik Hukum Legislasi Sebagai Socio-Equilibrium Di Indonesia”, Jurnal Ius Constituendum 4, no. 2 (2019): 149, http://dx.doi.org/10.26623/jic.v6i1.2915

${ }^{13}$ Doni Budiono, “Analisis Pengaturan Hukum Acara Kepailitan Dan Penundaan Kewajiban Pembayaran Utang”, JHAPER 4, no. 2 (2018): 110.

${ }^{14}$ Kheriah, "Independensi Pengurus Penundaan Kewajiban Pembayaran Utang (PKPU)Dalam Hukum Kepailitan”, Jurnal Ilmu Hukum 3, no. 2 (2013): 239.

${ }^{15}$ Sumurung P. Simaremare, et. al., "Politik Hukum Jangka Waktu Penundaan Kewajiban Pembayaran Utang Di Indonesia", Jurnal Ius Contituendum 6, no.1 (2021): 102, http://dx.doi.org/10.26623/jic.v6i1.2915 
Proceedings yang berlaku di Uni Eropa serta the United Nations Commission on International Trade Law (UNCITRAL) Model Law on Cross Border Insolvency yang dirancang dengan tujuan untuk membantu negara-negara melengkapi hukum kepailitan di negara masing-masing supaya lebih efektif dalam menangani perkara cross border insolvency. ${ }^{16}$

Dalam rangka menangani isu kepailitan lintas batas, berbagai negara memiliki pendekatan yang berbeda. Adapun negara-negara yang akan dilibatkan dalam hal ini yakni Jepang, dan Korea Selatan sebagai penganut sistem hukum civil law; Thailand dan Singapura sebagai penganut sistem hukum common law.

Sebelum dilakukan reformasi hukum kepailitan saat krisis tahun 1997, pendekatan prinsip teritorial melekat pada sistem hukum kepailitannya. Adapun peraturan hukum kepailitan Jepang terdahulu antara lain Bankruptcy Law dan Reorganization Law yang mengatur bahwa prosedur kepailitan asing ataupun putusan kepailitan pengadilan asing tidak dapat mencakup harta pailit debitur yang terdapat di wilayah Jepang sehingga putusan pengadilan asing tidak dapat berlaku efektif di dalam wilayah Jepang. Begitu juga dengan putusan pailit yang ditetapkan oleh pengadilan Jepang, tidak mencakup harta pailit debitur yang berada di luar wilayah Jepang.

Proses reformasi hukum kepailitan Jepang diawali dengan membentuk sebuah Committee on Insolvency Law Reform/Tosan ho bukai (Komite Reformasi Hukum Kepailitan) yang selanjutnya menghasilkan Law Relating to Recognition and Assistance for Foreign Insolvency Proceedings No. 129 of 2000 (Law 129/2000) sebagai perubahan terhadap undang-undang kepailitan sebelumnya dengan mengadopsi Model Law UNCITRAL dan berlaku efektif pada 1 April 2004. ${ }^{17}$

Kasus-kasus kepailitan yang bersifat lintas batas, sering terjadi suatu keadaan dimana terdapat debitur yang akan digugat pailit berkedudukan di suatu negara, tetapi ia juga melakukan kegiatan usaha di luar nergeri. Ataupun sebaliknya, debitur asing yang akan digugat pailit, tetapi ia memiliki kegiatan usaha ataupun aset di Indonesia. Hal tersebut mengakibatkan keadaan harta debitur yang melintasi batas negara sering menimbulkan permasalahan mengenai batasan harta debitur yang termasuk ke dalam boedel pailit. Terhadap keadaan yang seperti itu, sebenarnya baik pihak kreditur asing maupun kreditur lokal dapat mengajukan gugatan pailit di tempat kedudukan debitur maupun di tempat perusahaan debitur beroperasi selama memenuhi persyaratan ketentuan hukum kepailitan setempat. ${ }^{18}$

Contoh kasus yang pernah terjadi Indonesia akan mengeksekusi harta pailit kapal pesiar seorang debitur di negara Afrika. Ternyata tidak bisa karena Afrika tidak masuk di dalam organisasi UNCITRAL tersebut. Namun, jika Afrika masuk kedalam organisasi

\footnotetext{
${ }^{16}$ https://www.kk-advocates.com/new/read/pelaksanaan-cross-border-insolvency-di-indonesia diakses pada 22 Agustus 2021 pukul 21.15 WIB.

${ }^{17}$ Loura, Hardjaloka, "Kepailitan Lintas Batas Perspektif Hukum Internasional dan Perbandingannya Dengan Instrumen Nasional di Beberapa Negara", Yuridika 30, no. 3 (2015): 494, https://ejournal.unair.ac.id/YDK/article/view/1952/3643

18 Tedjasukman, Aspek-Aspek Hukum Perdata Internasional dalam Perkara-Perkara Kepailitan dan Pelaksanaannya dalam Praktek Berdasarkan Undang-Undang No. 4 Tahun 1998 jo Peraturan Pengganti UndangUndang No. 1 Tahun 1998: 94.
} 
UNCITRAL tersebut maka Kapal pesiar tersebut bisa kita eksekusi. Di karenakan Indonesia sudah masuk dalam organisasi UNCITRAL tersebut pada tahun 2019. Namun, tidak bisa mengeksekusi karna Afrika belum masuk ke dalam organisasi UNCITRAL Model Law.

\section{Problematika Eksekusi Harta Pailit Dalam Cross Border Insolvency}

Cross border insolvency tidak lepas dari permasalahan yang timbul dalam berbagai kasus kepailitan yang melintasi yurisdiksi negara. Selain problematika yang disebutkan di atas, terdapat problematika lain yang sering dihadapi yaitu dalam kaitannya dengan pengakuan (recognition) dan pelaksanaan (enforcement). Pelaksanaan (enforcement) mengandung arti yang lebih luas dan mendalam jika dibandingkan dengan pengakuan (recognition). ${ }^{19}$ Pelaksanaan suatu putusan memberikan konsekuensi yang lebih luas seperti dapat menimbulkan tindakan-tindakan aktif dari instansi-instansi tertentu yang berkaitan dengan peradilan atau administratif dari suatu pengakuan yang tidak selalu mengakibatkan adanya tindakan-tindakan yang aktif seperti itu. ${ }^{20}$

Di Indonesia sendiri sebagaimana ditentukan dalam Reglement Op De Burgelijke Rechtsvordering pada Pasal $436 \mathrm{Rv}$ yang menyatakan bahwa kecuali dalam hal-hal yang ditentukan oleh Pasal 724 KUHDagang dan lain-lain perundangan, maka tidak dapat dilaksanakan keputusan-keputusan yang diucapkan oleh hakim asing atau pengadilan asing dalam wilayah Republik Indonesia. ${ }^{21}$

Hambatan untuk melaksanakan putusan pengadilan asing di wilayah Republik Indonesia dianggap sebagai pelanggaran terhadap asas kedaulatan negara Indonesia sebagai suatu negara yang merdeka dan berdaulat. ${ }^{22}$ Hal tersebut disebabkan berlakunya prinsip teritorialitas yang dianut di Indonesia, dimana mengharuskan putusan yang ditetapkan di luar negeri, tidak dapat secara langsung dilaksanakan dalam wilayah lain atas kekuatannya sendiri.

Prinsip teritorialitas menyatakan bahwa akibat dari pernyataan pailit, proses dan pengakhiran kepailitan terbatas pada wilayah negara tempat pengadilan yang menangani kepailitan tersebut berada, sehingga putusan pailit suatu negara hanya dapat berlaku pada negara tempat dimana putusan pailit tersebut dikeluarkan. ${ }^{23}$ Hal tersebut tidak terlepas dari tidak diaturnya dalam perundang-undangan di Indonesia mengenai pengakuan dan pelaksanaan putusan pengadilan asing mengenai cross border insolvency. Dengan demikian, putusan pengadilan asing untuk melakukan eksekusi terhadap boedel pailit yang berada di dalam yurisdiksi Indonesia tidak dapat dilakukan.

Putusan pengadilan asing masih dapat diakui jika tidak meminta diadakannya eksekusi terhadap harta benda yang terletak dalam yurisdiksi Indonesia oleh pengadilan asing yang memang berwenang untuk membuat keputusan tersebut dan bahwa keputusan

\footnotetext{
19 Arindra Maharany, Tinjauan Hukum Terhadap Penerapan Instrumen Hukum Internasional Dalam Pengaturan Kepailitan Lintas Batas di Indonesia, Singapura, Malaysia, Thailand, Korea Selatan, dan Jepang, (Depok: Fakultas Hukum Universitas Indonesia, 2011): 57.

${ }^{20}$ Sudargo Gautama, Hukum Perdata Internasional Indonesia, (Bandung: PT Alumni, 2008): 182.

${ }^{21}$ Hindia Belanda, Reglement Op De Burgelijke Rechtsvorderin staatblaad 1849-63.

${ }^{22}$ Tineke Louise Tuegeh Longdong, Asas Ketertiban Umum dan Konvensi New York 1958, (Bandung: PT Citra Aditya Bakti, 1998): 187.

${ }^{23}$ Arindra Maharany, Op.Cit.
} 
tersebut memang telah dibuat secara sah dan bersifat constitutive dan declarotoir. Hal tersebut dikarenakan keputusan hanya menciptakan hak dan kewajiban dari orang yang bersangkutan dalam hubungan tertentu, dan karenanya mudah diakui oleh hakim luar negeri sebab tidak perlu untuk melakukan pelaksanaan.

Terdapat problematika yang lain yaitu tempat terletaknya boedel pailit dimana kasus yang sering terjadi dalam cross border insolvency yaitu terdapat debitur yang dinyatakan pailit memiliki aset di luar yurisdiksi negaranya. Maka, dengan tidak diakuinya putusan pengadilan asing untuk melakukan eksekusi terhadap boedel pailit diluar batas yurisdiksi negaranya karena asas kedaulatan negara. Oleh karena itu, kurator sebagai lembaga yang berwenang melakukan eksekusi boedel pailit akan kesulitan dalam menjalankan tugasnya. Hal tersebut tentu sangat merugikan kreditur sebagai pihak yang membutuhkan pelunasan atas piutangnya dari boedel pailit yang telah dieksekusi kurator.

\section{Mekanisme Pemberesan Harta Pailit Dalam Cross Border Insolvency}

Dalam kasus kepailitan terhadap benda tidak bergerak yang terletak di luar negeri berdasarkan Hukum Perdata Internasional akan berlaku pilihan hukum dan pilihan forum yang sebelumnya telah ditentukan oleh para pihak dalam suatu perjanjian utang piutangnya yang menentukan mengenai pilihan hukum, pilihan forum, dan pilihan domisili jika pilihan hukum terhadap penyelesaian sengketa tidak diperjanjikan. ${ }^{24}$

Terhadap kasus kepailitan yang sebelumnya sudah dilakukan perjanjian tentang penyelesaian sengketa tidak akan sulit, karena para pihak sudah sepakat atas hukum yang mana yang akan berlaku terhadap kasus kepailitan tersebut. Berbeda halnya dengan kasus kepailitan yang sebelumnya tidak dilakukan perjanjian penyelesaian sengketa, apabila suatu hari terjadi permasalahan dalam utang piutang tersebut maka akan sulit hukum yang mana yang harus diberlakukan.

Penyelesaian kasus kepailitan lintas batas negara (cross border insolvency) yang sebelumnya tidak dibuatkan perjanjian utang piutang yang meliputi penyelesaian sengketa dapat dilakukan dengan beberapa cara yaitu mengikuti proses pengadilan secara umum, menggunakan perjanjian bilateral, melalui hubungan diplomatik, atau menggunakan UNCITRAL Model Law on Cross Border Insolvency with Guide to enactment. Apabila akan melalui pengadilan secara umum, maka suatu negara harus mengajukan putusan kepailitan yang diputus oleh negara ke negara dimana boedel pailit berada dan mengikuti segala proses yang terlihat lebih rumit jika dalam kasus kepailitan lintas batas negara (cross border insolvency) melibatkan negara yang memiliki sistem hukum yang berbeda.

Terkait dengan permohonan pengakuan putusan pailit, jika suatu negara asing mengeluarkan putusan pailit dan diketahui debitur memiliki aset yang berada di Indonesia, maka terhadap putusan asing tersebut dapat dimohonkan agar diakui dan dapat digunakan sebagai dasar pengambilan aset tersebut melalui pengadilan negeri. Hal tersebut juga berlaku di negara lain seperti di Inggris, dimana terhadap benda tidak bergerak berlaku hukum Inggris, maka jika apabila dalam kepailitan terdapat aset yang

${ }^{24}$ Fuady, M. Penyelesaian Sengketa Bisnis Melalui Arbitrase, Jurnal Hukum Bisnis, (Jakarta: Yayasan Pengembangan Hukum Bisnis, 2002): 88. 
berada di negaranya dapat digunakan sebagai boedel pailit asal negara tersebut bersedia mengajukan permohonan pengakuan putusan melalui wakil yang ditunjuk oleh negaranya dan mengikuti hukum serta prosedur yang berlaku di Inggris. Akan tetapi, tidak selamanya pengajuan permohonan pengakuan putusan pailit suatu negara asing melalui pengadilan dapat dikabulkan oleh hakim pengadilan di negara yang diajukan permohonan.

Terhadap kasus kepailitan lintas batas negara (cross border insolvency) yang memiliki perjanjian bilateral khususnya mengenai penyelesaian sengketa kepailitan, maka dalam proses penyelesaiannya akan lebih mudah karena dapat menggunakan perjanjian tersebut sebagai dasar. Perjanjian bilateral mengenai kepailitan lintas batas negara (cross border insolvency) yang biasanya meliputi prinsip umum kerjasama dan koordinasi, mengenai penanganan sengketa tertentu seperti penangguhan, prosedur penyelesaian kalim, dan prosedur komunikasi antar pengadilan. Dalam UNCITRAL Model Law on Cross Border Insolvency with Guide to Enactment terdapat ketentuan mengenai perjanjian kerjasama antar negara mengenai kepailitan lintas batas negara. Perjanjian kepailitan ini dimaksudkan untuk memiliki efek mengikat bagi para pihak ataupun hanya untuk membentuk kerangka kerjasama yang tidak dimaksudkan untuk berkekuatan hukum tetap atau memaksakan kewajiban bagi para pihak. Perjanjian kepailitan juga dapat memasukkan berbagai ketentuan diantaranya dapat menunjukkan maksud untuk memiliki kekuatan hukum dan mengikat para pihak dan beberapa yang lain hanya berbentuk pernyataan itikad baik.

Eksekusi putusan pailit terhadap harta debitur yang berada diluar negeri, berarti eksekusi yang dilakukan melewati batas suatu negara (cross border bankruptcy) yakni menjalankan putusan pailit yang melintasi batas-batas suatu negara, sehingga aspek internasional akan muncul/kelihatan karena terdapat harta kekayaan debitur yang berada di dua negara atau lebih. Eksekusi putusan pailit yang dimaksudkan disini tentu mulai dari likuidasi sampai pemberesan kewajiban debitur terhadap kreditur dengan melakukan penjualan seluruh harta pailit melalui penjualan didepan umum/lelang (Pasal $185 \mathrm{UU}$ KPKPU) yang dilakukan oleh kurator. Sehubungan dengan eksekusi putusan pailit dari suatu pengadilan luar negeri/asing sebagaimana dimaksud di atas, terdapat 2 (dua) prinsip yang diakui secara universal yaitu sebagai berikut :

1) Prinsip Universalitas yang pada intinya mengakui bahwa suatu putusan pailit yang diucapkan di suatu negara mempunyai akibat hukum dimana saja orang yang dinyatakan pailit mempunyai harta benda.

2) Prinsip Teritorialitas yang pada intinya mengakui bahwa suatu putusan pailit hanya mengenai bagian harta benda debitur yang terletak di dalam wilayah negara tempat putusan kepailitan tersebut diucapkan. ${ }^{25}$

\section{E. PENUTUP}

Pada umumnya, cross border insolvency dapat terjadi bila aset atau utang seorang debitur terletak di lebih dari satu negara atau apabila debitur termasuk ke dalam jurisdiksi

${ }^{25}$ Rizka Rahmawati, "Eksekusi Aset Debitor yang Berada di Luar Negeri dalam Penyelesaian Sengketa Kepailitan”, (Bali: Fakultas Hukum Universitas Udayana, 2019): 130. 
pengadilan pada dua atau lebih negara. Pengaturan mengenai cross border insolvency terdapat pada beberapa regulasi regional dan internasional yaitu the Europian Community Regulation Insolvency Proceedings yang berlaku di Uni Eropa serta the United Nations Commission on International Trade Law (UNCITRAL) Model Law on Cross Border Insolvency yang dirancang dengan tujuan untuk membantu negara-negara melengkapi hukum kepailitan di negara masing-masing supaya lebih efektif dalam menangani perkara cross border insolvency. Negara-negara yang bisa mengeksekusi harta pailit di luar negeri tersebut harus menjadi anggota dari UNCITRAL. Jika salah satu negara dimana tempat harta pailit tersebut tidak masuk dalam anggota UNCITRAL maka, eksekusi harta pailit tersebut tidak bisa di eksekusi. Terdapat problematika yang lain yaitu tempat terletaknya boedel pailit dimana kasus yang sering terjadi dalam cross border insolvency yaitu terdapat debitur yang dinyatakan pailit memiliki aset di luar yurisdiksi negaranya. Maka, dengan tidak diakuinya putusan pengadilan asing untuk melakukan eksekusi terhadap boedel pailit diluar batas yurisdiksi negaranya karena asas kedaulatan negara. Oleh karena itu, kurator sebagai lembaga yang berwenang melakukan eksekusi boedel pailit akan kesulitan dalam menjalankan tugasnya. Hal tersebut tentu sangat merugikan kreditur sebagai pihak yang membutuhkan pelunasan atas piutangnya dari boedel pailit yang telah dieksekusi kurator. Penyelesaian kasus kepailitan lintas batas negara (cross border insolvency) yang sebelumnya tidak dibuatkan perjanjian utang piutang yang meliputi penyelesaian sengketa dapat dilakukan dengan beberapa cara yaitu mengikuti proses pengadilan secara umum, menggunakan perjanjian bilateral, melalui hubungan diplomatik, atau menggunakan UNCITRAL Model Law on Cross Border Insolvency with Guide to Enactment. Apabila akan melalui pengadilan secara umum, maka suatu negara harus mengajukan putusan kepailitan yang diputus oleh negara ke negara dimana boedel pailit berada dan mengikuti segala proses yang terlihat lebih rumit jika dalam kasus kepailitan lintas batas negara (cross border insolvency) melibatkan negara yang memiliki sistem hukum yang berbeda. Terkait dengan permohonan pengakuan putusan pailit, jika suatu negara asing mengeluarkan putusan pailit dan diketahui debitur memiliki aset yang berada di Indonesia, maka terhadap putusan asing tersebut dapat dimohonkan agar diakui dan dapat digunakan sebagai dasar pengambilan aset tersebut melalui pengadilan negeri. Hal tersebut juga berlaku di negara lain seperti di Inggris, dimana terhadap benda tidak bergerak berlaku hukum Inggris, maka jika apabila dalam kepailitan terdapat aset yang berada di negaranya dapat digunakan sebagai boedel pailit asal negara tersebut bersedia mengajukan permohonan pengakuan putusan melalui wakil yang ditunjuk oleh negaranya dan mengikuti hukum serta prosedur yang berlaku di Inggris. Akan tetapi, tidak selamanya pengajuan permohonan pengakuan putusan pailit suatu negara asing melalui pengadilan dapat dikabulkan oleh hakim pengadilan di negara yang diajukan permohonan. 


\section{DAFTAR PUSTAKA}

Adi Satrio., et. al, "Eksekusi Harta Debitur Pailit Yang Terdapat Di Luar Indonesia Dihubungkan Dengan Pemenuhan Hak-Hak Kreditur", Ganesha Law Review 2, no. 1 (2020): 101-106, https://ejournal2.undiksha.ac.id/index.php/GLR/article/download/126/89

Amalia, Jihan "Urgensi Implementasi UNCITRAL Model Law On Cross-Border Insolvency di Indonesia : Studi Komparasi Hukum Kepailitan Lintas Batas Indonesia dan Singapura", Jurnal Hukum Bisnis Bonum Commune 2, no. 2 (2019): 164, https://core.ac.uk/download/pdf/229337923.pdf

Budiono, Doni, "Analisis Pengaturan Hukum Acara Kepailitan Dan Penundaan Kewajiban Pembayaran Utang", JHAPER 4, no. 2 (2018): 110.

Dicky Moallavi, Asnil, “UNCITRAL Model Law on Cross Border Insolvency Sebagai Model Pengaturan Kepailitan Lintas Batas Indonesia dalam Integrasi Ekonomi ASEAN", Undang: Jurnal Hukum 1, no. 2 (2018): 328, https://ujh.unja.ac.id/index.php/home/article/view/22/15

Dinar Kirana Ratri, Pramesthi and Emmy Latifah, "Urgensi Penerapan Aturan Kepailitan Lintas Batas Negara Berdasarkan UNCITRAL Model Law On CrossBorder Insolvency di ASEAN, Belli ac Pacis 2, no. 2 (2016): 7, https://jurnal.uns.ac.id/belli/article/view/27448/18982

Fuady, M, 2002, Penyelesaian Sengketa Bisnis Melalui Arbitrase, Jurnal Hukum Bisnis, Yayasan Pengembangan Hukum Bisnis, Jakarta.

Gautama, Sudargo, 2008, Hukum Perdata Internasional Indonesia, PT Alumni, Bandung.

Hidayat, Arif, and Zaenal Arifin, "Politik Hukum Legislasi Sebagai Socio-Equilibrium Di Indonesia", Jurnal Ius Constituendum 4, no. 2 (2019): 149, http://dx.doi.org/10.26623/jic.v6i1.2915

https://www.liputan6.com/bisnis/read/4020268/melihat-pertumbuhan-ekonomi-diasean-indonesia-peringkat-berapa, diakses pada tanggal 17 Januari 2021

https://www.kk-advocates.com/new/read/pelaksanaan-cross-border-insolvency-diindonesia diakses pada 22 Agustus 2021.

Kheriah, "Independensi Pengurus Penundaan Kewajiban Pembayaran Utang (PKPU) Dalam Hukum Kepailitan”, Jurnal Ilmu Hukum 3, no. 2 (2013): 239.

Longdong, Tineke Louise Tuegeh, 1958, Asas Ketertiban Umum dan Konvensi New York 1958, PT Citra Aditya Bakti, Bandung.

Loura, Hardjaloka, "Kepailitan Lintas Batas Perspektif Hukum Internasional dan Perbandingannya Dengan Instrumen Nasional di Beberapa Negara", Yuridika 30, no. 3 (2015): 494, https://e-journal.unair.ac.id/YDK/article/view/1952/3643

Maharany, Arindra, 2011, Tinjauan Hukum Terhadap Penerapan Instrumen Hukum Internasional Dalam Pengaturan Kepailitan Lintas Batas di Indonesia, Singapura, Malaysia, Thailand, Korea Selatan, dan Jepang, Fakultas Hukum Universitas Indonesia, Depok.

Nugroho, Susanto Adi, 2018, Hukum Kepailitan di Indonesia Dalam Teori dan Praktik Serta Penerapan Hukumnya, Prenadamedia Group, Jakarta. 
P. Simaremare, Sumurung et. al., "Politik Hukum Jangka Waktu Penundaan Kewajiban Pembayaran Utang Di Indonesia”, Jurnal Ius Contituendum 6, no.1 (2021): 102. http://dx.doi.org/10.26623/jic.v6i1.2915

Rahmawati, Rizka, 2019, Eksekusi Aset Debitur yang Berada di Luar Negeri dalam Penyelesaian Sengketa Kepailitan, Fakultas Hukum Universitas Udayana, Bali. Ranitya Ganindha dan Nadhira Putri Indira, "Kewenangan Kurator Dalam Eksekusi Aset Debitur Pada Kepailitan Lintas Batas Negara", Arena Hukum 13, no. 2 (2020): 337, https://doi.org/10.21776/ub.arenahukum.2020.01302.8

Shubhan, Hadi, 2019, Hukum Kepailitan: Prinsip, Norma, dan Praktik di Peradilan, Prenadamedia Group, Jakarta.

Sutopo, H.B, 1998, Metodologi Hukum Kualitatif Bagian II, UNS Press, Jakarta.

Sutrisno, Endang, 2013, Bunga Rampai Hukum dan Globalisasi, In Media, Jakarta.

Winarno, Budi, 2004, Globalisasi Wujud Imperlism Baru Peran Negara Dalam Perkembangan, Tajidu Press, Yogyakarta

Tedjasukman, Aspek-Aspek Hukum Perdata Internasional dalam Perkara-Perkara Kepailitan dan Pelaksanaannya dalam Praktek Berdasarkan Undang-Undang No. 4 Tahun 1998 jo Peraturan Pengganti Undang-Undang No. 1 Tahun 1998 Undang-Undang Nomor 37 Tahun 2004 tentang Kepailitan dan Penundaan Kewajiban Pembayaran Utang 